\title{
Optimal Available Phosphorus Levels in Diets Containing Different Dicalcium Phosphate Particle Sizes for Japanese Quails
}

Original Article

\section{-Author(s)}

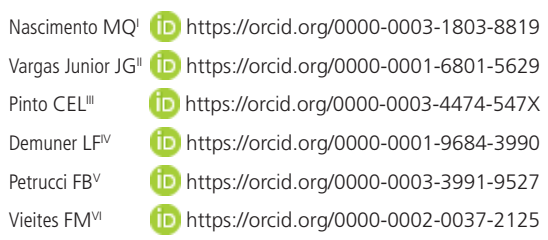

State University of Sao Paulo "Julio de Mesquita Filho"/ Faculty of Agrarian Sciences (FCAV), Department of Animal Science, Jaboticabal, SP, Brazil.

Federal University of Espirito Santo- Department of Animal Science, Alegre, ES, Brazil.

II BM Comércio de Produtos Químicos e Biológicos Ltda. Santa Maria de Jetibá, ES, Brazil.

Science, Technology and Innovation Agency of the state of Mato Grosso (SECITEC), Cuiabá, MT, Brazil.

COOPEAVI, Santa Maria de Jetibá, ES, Brazil. Federal University of Juiz de Fora, Juiz de Fora, MG, Brazil

\section{Mail Address}

Corresponding author e-mail address Mariana Quintino do Nascimento

Department of Animal Science, UNESP Universidade Estadual Paulista, Via de acesso Prof. Paulo Donato Castellane, s/n Zip code: 14.884-900 - Jaboticabal, SP, Brazil.

Phone: +55 16 3209-7503

Email: mariana.qn@mail.com

\section{-Keywords}

Egg quality, macrominerals, mineral nutrition.

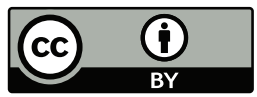

Submitted: 31/January/2019

Approved: 27/June/2019

\section{ABSTRACT}

This experiment was conducted to investigate the effects available phosphorus levels and dicalcium phosphate particle size on the live performance, and egg parameters and bone parameters of Japanese quails in lay. The experimental diets were based on corn and soybean meal and formulated to contain $2900 \mathrm{kcal}$ metabolizable energy (ME) $\mathrm{kg}^{-1}, 200 \mathrm{~g} \mathrm{~kg}^{-1}$ crude protein (CP) and $30.5 \mathrm{~g} \mathrm{~kg}^{-1}$ calcium (Ca). Feeds were supplied ad libitum. Laying Japanese quails ( $n=720,20$-wk-old) were distributed in a completely randomized design in a $5 \times 2$ factorial arrangement, with five levels of available phosphorus (avP; 1.0, 2.0, 3.0, 4.0, $5.0 \mathrm{~g} \mathrm{~kg}^{-1}$ ) and two dicalcium phosphate particle sizes (fine orcoarse), totaling ten treatments with eight replicates of nine birds each. Egg laying rate, feed intake per bird per day, egg weight, egg mass, feed conversion ratio per egg mass and per dozen eggs, eggshell, yolk and albumen relative and absolute weights, as well as bone ash, phosphorus, calcium, and magnesium contents were evaluated. Based on the results, avP recommendations for 20- to 32-wk-old laying Japanese quails varies according with phosphate source particle size and the dietary avP levels of $4.40 \mathrm{~g} \mathrm{~kg}^{-1}$ and $3.85 \mathrm{~g} \mathrm{~kg}^{-1}$ avP levels when using fine and coarse particle dicalcium phosphate, respectively, yielded the best results.

\section{INTRODUCTION}

Available phosphorus (avP) requirements should be taken into consideration when formulating diets for laying quails, as they have higher requirements than younger birds for bone remodeling and egg deposition (Costa et al., 2010). Phosphorus (P) is a component of the nucleic acids involved in cell growth and differentiation, and it is essential for energy use and transfer (in the form of ATP), fat transport, amino acid and protein synthesis, and also participates in the control of appetite, consequently affecting feed efficiency (Runho et al., 2001). This mineral is the third most expensive nutrient in non-ruminant diets, after energy and protein sources, in particular sulfur amino acids and lysine sources. Dietary $P$ has been extensively researched relative to its economic and physiological importance, but also as a potential environmental polluting agent (Pinheiro et al., 2015).

However, there is limited research on the inclusion of granulated phosphate in the diet of Japanese quails. Griffith \& Schexnailder (1970) observed that phosphate sources with large particle sizes increases phosphorus availability to laying hens, as it increases phosphate retention time in the gizzard, allowing its slow release in that acid environment, and consequently improving its digestibility. The solubility of P increases with the degree of grinding of phosphate sources. The eggshell is formed during the night, and part of the ingested $\mathrm{P}$ is directed to yolk 
Nascimento MQ, Vargas Junior JG, Pinto CEL, Demuner LF, Petrucci FB, Vieites FM

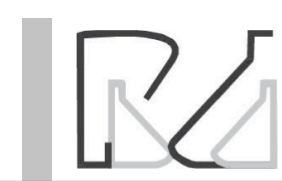

deposition and another part is combined with calcium to be deposited in the bone.

The release of calcium from the bone is accompanied by phosphorus, significantly increasing the level of this mineral in the bloodstream. Therefore, special attention should be given to dietary phosphorus levels, because excessive $P$ impairs the release of calcium from the bone and prevents adequate eggshell mineralization. Calcium and $\mathrm{P}$ absorption, metabolism, and excretion are closely linked (Salter et al., 1931). According to Furtado (1991), the best level of phosphorus (P) absorption occurs when dietary $C$ a levels provide for adequate Ca:avP ratio. Excessive Ca levels may reduce $\mathrm{P}$ absorption by producing an insoluble complex with myo-inositol and trace elements in the intestinal lumen, emphasizing the need to obtain adequate balance between $\mathrm{Ca}$ and avP levels in quail diets.

Therefore, the objective of this study was to evaluate the effect of dicalcium phosphate particle size and dietary available phosphorus levels on the production performance, egg quality, and bone characteristics of laying Japanese quails.

\section{MATERIALS AND METHODS}

This study was approved by the Animal Welfare Commission of the Federal University of Espirito Santo and conducted in compliance with animal welfare regulations under protocol number 024/2012.

The study was conducted at the Department of Animal Science, Federal University of Espirito Santo, Alegre, SP, from January to April 2013.

The experimental period of 84 days was subdivided into four periods of 21 days. Seven hundred and twenty 20-wk-old Japanese quails were housed in battery cages, and exposed to $16 \mathrm{~h}$ light/day, and had ad libitum access to feed and water. Birds were randomly distributed according to a completely randomized experimental design in a 5x2 factorial arrangement (five avP levels and two dicalcium phosphate particle sizes), with eight replicates of nine birds each.

Diets were formulated according to Rostagno et al. (2011) to contain adequate levels of all nutrients

Optimal Available Phosphorus Levels in Diets Containing Different Dicalcium Phosphate Particle Sizes for Japanese Quails

and energy, except for avP. Dicalcium phosphate (fine or coarse particles) and limestone were added to the basal diet (Table 1) in replacement of inert material (sand)in order to obtain five different avP levels $\left(1.0,2.0,3.0,4.0,5.0 \mathrm{~g} \mathrm{~kg}^{-1}\right)$ for each particle size (Table 2 ).

Table 1 - Ingredients and calculated nutritional composition of the basal diet.

\begin{tabular}{|c|c|c|}
\hline Ingredient & & Amount $\left(\mathrm{g} \mathrm{kg}^{-1}\right)$ \\
\hline Corn & & 572.30 \\
\hline Soybean meal $45 \%$ & & 241.34 \\
\hline Corn gluten $60 \%$ & & 71.84 \\
\hline Soybean oil & & 15.52 \\
\hline Limestone & & 11.01 \\
\hline Salt & & 5.87 \\
\hline L-Lysine HCL & & 3.18 \\
\hline DL-Methionine & & 1.01 \\
\hline L-Threonine & & 0.59 \\
\hline Choline chloride $60 \%$ & & 0.60 \\
\hline Vitamin supplement $^{1}$ & & 1.00 \\
\hline Mineral supplement ${ }^{2}$ & & 0.50 \\
\hline Zinc bacitracin & & 0.15 \\
\hline $\mathrm{BHT}^{3}$ & & 0.10 \\
\hline Inert material (sand) & & 75.00 \\
\hline TOTAL & & 1000.00 \\
\hline \multicolumn{3}{|l|}{ Calculated Composition } \\
\hline Metabolizable Energy & $\left(\mathrm{MJ} \mathrm{kg}^{-1}\right)$ & 12.14 \\
\hline Crude protein & $\left(\mathrm{g} \mathrm{kg}^{-1}\right)$ & 200.00 \\
\hline Digestible lysine & $\left(\mathrm{g} \mathrm{kg}^{-1}\right)$ & 10.50 \\
\hline Digestible methionine & $\left(\mathrm{g} \mathrm{kg}^{-1}\right)$ & 4.27 \\
\hline Digestible methionine + cystine & $\left(\mathrm{g} \mathrm{kg}^{-1}\right)$ & 7.20 \\
\hline Digestible threonine & $\left(\mathrm{g} \mathrm{kg}^{-1}\right)$ & 7.30 \\
\hline Digestible arginine & $\left(\mathrm{g} \mathrm{kg}^{-1}\right)$ & 11.14 \\
\hline Digestible tryptophan & $\left(\mathrm{g} \mathrm{kg}^{-1}\right)$ & 1.90 \\
\hline Calcium & $\left(\mathrm{g} \mathrm{kg}^{-1}\right)$ & 5.00 \\
\hline Available phosphorus & $\left(\mathrm{g} \mathrm{kg}^{-1}\right)$ & 1.00 \\
\hline Linoleic acid & $\left(\mathrm{g} \mathrm{kg}^{-1}\right)$ & 21.33 \\
\hline Sodium & $\left(\mathrm{g} \mathrm{kg}^{-1}\right)$ & 2.50 \\
\hline Chlorine & $\left(\mathrm{g} \mathrm{kg}^{-1}\right)$ & 0.07 \\
\hline Potassium & $\left(\mathrm{g} \mathrm{kg}^{-1}\right)$ & 6.67 \\
\hline Electrolyte balance & $\left(\mathrm{mEqkg}^{-1}\right)$ & 166.41 \\
\hline \multicolumn{3}{|c|}{$\begin{array}{l}{ }^{1} \text { Mineral supplement (per } \mathrm{kg} \text { of diet): } 55000 \mathrm{mg} \text { of } \mathrm{Zn} \text { (min.); } 700 \mathrm{mg} \text { of I (min.); } \\
10000 \mathrm{mg} \text { of } \mathrm{Cu} \text { (min.); } 78000 \mathrm{mg} \text { of } \mathrm{Mn} \text { (min.); } 48000 \mathrm{mg} \text { of Fe (min.); } 200 \mathrm{mg} \text { of Co. }\end{array}$} \\
\hline \multicolumn{3}{|c|}{$\begin{array}{l}\text { Vitamin supplement (per kg of diet): } 3.75 \text { mg Folic acid; } 60 \mathrm{mg} \text { Pantothenic acid; } \\
0.125 \mathrm{mg} \text { Biotin; } 175 \mathrm{mg} \text { Niacin; Vitamin A } 40000 \text { Ul; Vitamin B1 } 7.5 \mathrm{mg} \text {; Vitamin E } \\
75 \text { Ul; Vitamin B1260 mcg; Vitamin B2 25mg; Vitamin B6 } 14 \text { mg; Vitamin D310000 } \\
\text { Ul; Vitamin K3 } 9 \text { mg; } 1 \text { mg of Selenium; }\end{array}$} \\
\hline${ }^{3}$ Butyl-hydroxy toluene $5 \mathrm{mg}$. & & \\
\hline
\end{tabular}

Table 2 - Dicalcium phosphate and limestone inclusion levels in substitution of inert material.

\begin{tabular}{lcccc}
\hline $\operatorname{avP}\left(\mathrm{g} \mathrm{kg}^{-1}\right)$ & Dicalcium phosphate $\left(\mathrm{g} \mathrm{kg}^{-1}\right)$ & $\begin{array}{c}\text { Limestone } \\
\left(\mathrm{g} \mathrm{kg}^{-1}\right)\end{array}$ & 66.41 & $\begin{array}{c}\text { Inert material } \\
\left(\mathrm{g} \mathrm{kg}^{-1}\right)\end{array}$ \\
\hline 1.0 & 0.00 & 62.92 & $30: 1$ & 8.60 \\
2.0 & 5.41 & 59.51 & $15: 1$ & 6.69 \\
3.0 & 10.81 & 56.07 & $10: 1$ & 4.69 \\
4.0 & 16.21 & 52.63 & $7: 1$ & 2.73 \\
5.0 & 21.62 & $6: 1$ & 0.75 \\
\hline
\end{tabular}


Nascimento MQ, Vargas Junior JG, Pinto CEL, Demuner LF, Petrucci FB, Vieites FM

\section{Optimal Available Phosphorus Levels in Diets Containing Different Dicalcium Phosphate Particle Sizes for Japanese Quails}

Fine (FPP) or coarse (CPP) phosphate particle sizes measured, respectively, geometric mean diameter (GMD) of 148 and $325 \mu \mathrm{m}$ and geometric standard deviation (GSD) of 0.97 and 2.14. The determination of phosphate particle size was calculated using the equation described by Handerson \& Perry (1955).

Birds were allotted to the treatments in order to obtain uniform body weight and egg production among replicates. Average egg weight, egg mass and feed conversion ratio ( $\mathrm{g}$ of feed per $\mathrm{g}$ of egg mass FCRem; and kg of feed per dozen eggs - FCRdz) were determined in the eggs collected during the last four days of each $21-d$ period. Feed intake was determined as the difference between feed provided during the entire experimental period and feed residues at the end of the experimental period.

Bone ash, phosphorus, calcium, and magnesium contents were determined in the right tibiotarsus of three birds per repetition according to the methodology described by Silva (2009).

The obtained data were submitted to analyses of variance and of regression (polynomial models) using the software SAEG (System for Statistical Analysis and Genetics, 1997) of the Federal University of Viçosa. Independently of the effects of the interaction avP level $x$ phosphate particle size, the results were analyzed in order to determine the effect of phosphorus levels within each studied particle size in order to obtain the avP recommendations as a function of dicalcium phosphate particle size.

\section{RESULTS AND DISCUSSION}

The results showed dietary avP levels has a quadratic effect laying rate (LR) and feed intake (FI), independently of phosphate particle size (Table 3).

Table 3 - Laying rate (LR), feed intake (FI), and their respective equations of Japanese quails fed diets containing different avP levels from fine (FPP - 148 $\mu \mathrm{m}$ ) orcoarse (CPP- $325 \mu \mathrm{m})$ phosphate particle sizes.

\begin{tabular}{|c|c|c|c|c|}
\hline \multirow{2}{*}{$\operatorname{AvP}\left(\mathrm{g} \mathrm{kg}^{-1}\right)$} & \multicolumn{2}{|l|}{$\operatorname{LR}(\%)$} & \multicolumn{2}{|c|}{$\mathrm{Fl}(\mathrm{g})$} \\
\hline & FPP & CPP & FPP & CPP \\
\hline 1.0 & 71.63 & 71.63 & 24.55 & 24.55 \\
\hline 2.0 & 79.35 & 77.91 & 24.98 & 25.29 \\
\hline 3.0 & 78.64 & 79.20 & 24.96 & 25.28 \\
\hline 4.0 & 80.73 & 78.10 & 25.86 & 24.75 \\
\hline 5.0 & 81.70 & 79.67 & 25.28 & 24.61 \\
\hline Significance & $p \leq 0.002$ & $p \leq 0.074$ & $p \leq 0.020$ & $p \leq 0.055$ \\
\hline Effect & Q & Q & Q & Q \\
\hline CV $(\%)$ & \multicolumn{2}{|l|}{6.298} & \multicolumn{2}{|c|}{3.557} \\
\hline Parameter & Equation & $R^{2}$ & Max point & Estimated level (\%) \\
\hline LR (FPP) & $\mathrm{LR}=66.61+67.40 \mathrm{FPP}-76.53 \mathrm{FP} P 2$ & 0.88 & $81.46 \%$ & 0.44 \\
\hline LR (CPP) & $L R=66.52+66.84 C P P-84.30 C P P^{2}$ & 0.78 & $79.77 \%$ & 0.26 \\
\hline $\mathrm{Fl}(\mathrm{FPP})$ & $\mathrm{FI}=23.88+7.03 \mathrm{FPP}-7.83 \mathrm{FPP}^{2}$ & 0.66 & $25.40 \mathrm{~g}$ & 0.44 \\
\hline $\mathrm{FI}(\mathrm{CPP})$ & $\mathrm{FI}=23,89+9.33 C P P-16.24 C P P^{2}$ & 0.77 & $25.22 \mathrm{~g}$ & 0.28 \\
\hline
\end{tabular}

$\mathrm{Q}=$ Quadratic effect; $N S=$ non-significant effect; $C V=$ Coefficient of variation; $C P P=$ coarse particle size; $F P P=$ fine particle size;

The level of $1.0 \mathrm{~g} \mathrm{~kg}^{-1}$ of available phosphorus refers to the basal diet with no addition of dicalcium phosphate.

The highest LR response was obtained with 0.44 and $0.26 \%$ avP in the diets with FPP and CPP, respectively grain (Table 3 ). The obtained $L R$ values may be associated with phosphorus role in the absorption of other minerals, mainly calcium and magnesium. In addition, the lower avP recommendation estimated when CPP phosphate was added (Table 3) may be due to the longer retention time of coarse phosphate particles in the gizzard compared with FPP, which readily supply a higher concentration of ionized and solubilized phosphorus $(P)$ in the intestinal lumen. The presence of high $\mathrm{P}$ levels in the intestine, as a result of high dietary $\mathrm{Ca}: \mathrm{P}$ ratio, increases intestinal $\mathrm{pH}$, which results in the formation of $P$ complexes with calcium, zinc, and manganese, consequently impairing the absorption of these minerals (Oderkirk, 1998). However, Vieira et al. (2012) did not observe any significant effect of 0.10 to $0.31 \%$ avP levels on the egg production of Japanese quails, neither Amoah et al. (2012) with increasing dietary avP levels.

The highest FI was determined in birds fed $0.44 \%$ avP from FPP and $0.28 \%$ avP from CPP (Table 3), and may be explained by the higher $\mathrm{P}$ availability in FPP, releasing $\mathrm{P}$ ions in the intestinal lumen, causing greater reaction with other nutrients and forming inorganic phosphates, consequently reducing $\mathrm{P}$ absorption ( $\mathrm{Li}$ et al., 2016; DiMeglio \& Imel, 2019). Therefore, birds need to increase their feed intake to supply their 
Nascimento MQ, Vargas Junior JG, Pinto CEL, Demuner LF, Petrucci FB, Vieites FM

\section{Optimal Available Phosphorus Levels in Diets Containing Different Dicalcium Phosphate Particle Sizes for Japanese Quails}

The heaviest eggs in birds fed FPP were determined at $0.196 \%$ avP level. These results disagree with those reported by Vieira et al. (2012), who evaluated different dietary P levels (0.10 to $0.31 \%)$ and did not observe any effect egg weight.

Egg mass is the ratio between laying rate and egg weight, and any changes in one of these parameters may have significant effects on egg mass. The estimated avP level when using FPP $(0.392 \%)$ is very close to that obtained with CPP $(0.385 \%)$. Therefore, the EM differences obtained are a result to laying rate rather than to egg weight, as laying rate tends to decrease and egg size to increase as birds age, and indicate that laying Japanese quails maintain egg

Table 4 - Egg weight (EW), egg mass (EM), feed conversion ratio (FCR) per $g$ and per dozen and their respective equations.

\begin{tabular}{|c|c|c|c|c|c|c|c|c|}
\hline \multirow[t]{2}{*}{$\operatorname{avP}\left(\mathrm{g} \mathrm{kg}^{-1}\right)$} & \multicolumn{2}{|c|}{ EW (g) } & \multicolumn{2}{|c|}{$\begin{array}{c}\mathrm{EM} \\
(\mathrm{g} \text { egg/bird/d) }\end{array}$} & \multicolumn{2}{|c|}{$\mathrm{FCR}(\mathrm{g} / \mathrm{g})$} & \multicolumn{2}{|c|}{$\mathrm{FCR}(\mathrm{kg} / \mathrm{dz})$} \\
\hline & FPP & CPP & FPP & CPP & FPP & CPP & FPP & CPP \\
\hline 1.0 & 11.66 & 11.66 & 8.35 & 8.35 & 2.946 & 2.946 & 0.412 & 0.412 \\
\hline 2.0 & 11.74 & 11.62 & 9.31 & 9.05 & 2.690 & 2.768 & 0.378 & 0.389 \\
\hline 3.0 & 11.62 & 11.62 & 9.13 & 9.20 & 2.763 & 2.733 & 0.382 & 0.384 \\
\hline 4.0 & 11.60 & 11.53 & 9.37 & 9.01 & 2.777 & 2.753 & 0.385 & 0.382 \\
\hline 5.0 & 11.44 & 11.55 & 9.34 & 9.20 & 2.731 & 2.708 & 0.372 & 0.373 \\
\hline Significance & $p \leq 0.039$ & $p>0.05$ & $p \leq 0.02$ & $p \leq 0.075$ & $p \leq 0.002$ & $p \leq 0.011$ & $p \leq 0.065$ & $p \leq 0.002$ \\
\hline Effect & $\mathrm{Q}$ & NS & $\mathrm{Q}$ & $\mathrm{Q}$ & $\mathrm{L}$ & $\mathrm{L}$ & $\mathrm{Q}$ & L \\
\hline CV (\%) & \multicolumn{2}{|c|}{2.047} & \multicolumn{2}{|c|}{6.404} & 5.723 & \multicolumn{3}{|c|}{6.186} \\
\hline Parameter & \multicolumn{2}{|c|}{ Equation } & \multicolumn{2}{|c|}{$\mathrm{R}^{2}$} & Max point & \multicolumn{3}{|c|}{ Estimated Level (\%) } \\
\hline EW (FPP) & \multicolumn{2}{|c|}{$E W=11.59+1.08 \mathrm{FPP}-2.76 \mathrm{FPP}^{2}$} & \multicolumn{2}{|c|}{0.74} & 11.70 & \multicolumn{3}{|c|}{0.196} \\
\hline EM (FPP) & \multicolumn{2}{|c|}{$\mathrm{EM}=7.71+8.73 \mathrm{FPP}-11.15 \mathrm{FPP}^{2}$} & \multicolumn{2}{|c|}{0.90} & 9.42 & \multicolumn{3}{|c|}{0.392} \\
\hline EM (CPP) & \multicolumn{2}{|c|}{$\mathrm{EM}=7.78+7.50 C P P-9.73 C \mathrm{PP}^{2}$} & \multicolumn{2}{|c|}{0.74} & 9.23 & \multicolumn{3}{|c|}{0.385} \\
\hline FCRem (FPP) & \multicolumn{2}{|c|}{$\mathrm{FCCPP}=2.88-0.34 \mathrm{FPP}$} & \multicolumn{2}{|c|}{0.78} & ---- & \multicolumn{3}{|c|}{$>0.5$} \\
\hline FCRem (CPP) & \multicolumn{2}{|c|}{$F C C P P=0.29-0.49 C P P$} & \multicolumn{2}{|c|}{0.59} & ---- & \multicolumn{3}{|c|}{$>0.5$} \\
\hline FCRdz (FPP) & \multicolumn{2}{|c|}{$\begin{array}{l}\mathrm{FCKGDZ}=0.43-0.25 \mathrm{FPP}+ \\
0.29 \mathrm{FPP} 2\end{array}$} & \multicolumn{2}{|c|}{0.81} & 0.376 & \multicolumn{3}{|c|}{0.427} \\
\hline FCRdz (CPP) & \multicolumn{2}{|c|}{$\mathrm{FCKGDZ}=0.41-0.09 C P P$} & \multicolumn{2}{|c|}{0.79} & ----- & \multicolumn{3}{|c|}{$>0.5$} \\
\hline
\end{tabular}

$\mathrm{CPP}=$ coarse particle size dicalcium phosphate; $\mathrm{FPP}=$ fine particle size dicalcium phosphate.

mass for longer than laying rate (Flemming, 2005). However, the EM results disagree with those observed by Amoah et al. (2012) and Vieira et al. (2012), who evaluated increasing dietary avP levels but did not find any significant effects on egg mass.

Feed conversion ratio per egg mass ( $\mathrm{g}$ feed/g egg) and per dozen eggs ( $\mathrm{kg}$ feed/dozen eggs) improved $(p<0.05)$ as dietary avP levels increased, suggesting that $P$ requirements were supplied earlier when quails were fed higher avP levels had more $P$ available. When the diets included CPP, FCR per dozen eggs improved up to $0.427 \%$ avP. Garcia et al. (2000) observed a linear improvement in FCR per dozen eggs as avP levels increased. Phosphorus metabolism is directly related to the dietary Ca:avP ratio, which influences feed intake and laying rate in both laying Japanese quails and chickens (Almeida et al., 2009; Vieira et al., 2012).

The effects of dietary avP levels on albumen (ALW and ALRW), yolk (YW and YRW) and eggshell (ESW and ESRW) absolute and relative weights are presented in Table 5. Albumen (FPP) and eggshell (CPP) absolute weights and eggshell relative weight (CPP) present a quadratic response to dietary avP levels, whereas linear responses were obtained for albumen (FPP), yolk (FPP) and eggshell (FPP) relative weights. No influence of avP levels were detected on eggshell (FPP) and albumen (CPP)absolute weights. However, Ribeiro et al. (2016) did not find any effect of dietary avP levels on eggshell weight. 
Nascimento MQ, Vargas Junior JG, Pinto CEL, Demuner LF, Petrucci FB, Vieites FM

Table 5 - Characteristics of quail eggs.

\begin{tabular}{|c|c|c|c|c|c|c|}
\hline \multirow{3}{*}{$\operatorname{avP}\left(\mathrm{g} \mathrm{kg}^{-1}\right)$} & \multicolumn{6}{|c|}{ Absolute weight (g) } \\
\hline & \multicolumn{2}{|c|}{ Albumen } & \multicolumn{2}{|c|}{ Yolk } & \multicolumn{2}{|c|}{ Eggshell } \\
\hline & FPP & CPP & FPP & CPP & FPP & CPP \\
\hline 1.0 & 6.85 & 6.85 & 3.84 & 3.84 & 0.96 & 0.96 \\
\hline 2.0 & 7.12 & 6.93 & 3.67 & 3.74 & 0.94 & 0.94 \\
\hline 3.0 & 6.94 & 6.89 & 3.74 & 3.72 & 0.93 & 0.98 \\
\hline 4.0 & 6.88 & 6.90 & 3.78 & 3.67 & 0.94 & 0.95 \\
\hline 5.0 & 6.83 & 6.87 & 3.65 & 3.74 & 0.94 & 0.93 \\
\hline Significance & $P \leq 0.062$ & $p>0.05$ & $p>0.05$ & $p>0.05$ & $p>0.05$ & $P \leq 0.030$ \\
\hline Effect & NS & NS & NS & NS & NS & Q \\
\hline \multirow[t]{2}{*}{$\mathrm{CV}(\%)$} & \multicolumn{2}{|c|}{2.92} & \multicolumn{2}{|c|}{4.31} & \multicolumn{2}{|c|}{4.17} \\
\hline & \multicolumn{6}{|c|}{ Relative weight (\%) } \\
\hline & \multicolumn{2}{|c|}{ Albumen } & \multicolumn{2}{|c|}{ Yolk } & \multicolumn{2}{|c|}{ Eggshell } \\
\hline $\operatorname{avP}\left(\mathrm{g} \mathrm{kg}^{-1}\right)$ & FPP & CPP & FPP & CPP & FPP & CPP \\
\hline 1.0 & 58.78 & 58.78 & 32.97 & 32.97 & 8.24 & 8.24 \\
\hline 2.0 & 60.68 & 59.68 & 31.31 & 32.20 & 8.01 & 8.12 \\
\hline 3.0 & 59.73 & 59.39 & 32.24 & 32.08 & 8.02 & 8.51 \\
\hline 4.0 & 59.29 & 59.82 & 32.57 & 31.88 & 8.12 & 8.28 \\
\hline 5.0 & 59.79 & 59.53 & 31.95 & 32.41 & 8.25 & 8.05 \\
\hline Significance & $p \leq 0.007$ & $p>0.05$ & $p \leq 0.014$ & $p>0.05$ & $p \leq 0.066$ & $p \leq 0.015$ \\
\hline Effect & L & NS & L & NS & NS & $\mathrm{Q}$ \\
\hline CV $(\%)$ & \multicolumn{2}{|c|}{2.17} & \multicolumn{2}{|c|}{3.68} & \multicolumn{2}{|c|}{3.75} \\
\hline
\end{tabular}

$\mathrm{CPP}=$ coarse particle size dicalcium phosphate; $\mathrm{FPP}=$ fine particle size dicalcium phosphate;

$\mathrm{Q}=$ Quadratic effect; $\mathrm{NS}=$ no significant effect; $\mathrm{CV}=$ Coefficient of variation

The level of $1.0 \mathrm{~g} \mathrm{~kg}^{-1}$ of available phosphorus refers to the basal diet with no addition of dicalcium phosphate.

There was no effect ( $p>0.05$ ) of dietary avP levels on the absolute weights of the albumen and yolk, independently of dicalcium phosphate particle size, or of the eggshell of birds fed FPP. Albumen and yolk relative weights of birds fed CPP, and eggshell relative weight of birds fed CPP also did not respond to avP levels ( $p>0.05)$.

Dietary avP levels had a quadratic effect on ESRW when the diets contained CPP, but no changes were observed when FPP was added to the diets. These results are consistent with those of Costa et al. (2010), who observed quadratic eggshell at $0.43,0.41,0.42$, and $0.27 \%$ avP in the diet.
The obtained quadratic response of albumen absolute weight (ALW) to increasing avP level in the diets containing CPP disagrees with Costa et al. (2011), who did not find any influence of avP levels on albumen absolute or relative weights.

Dietary avP levels had a linear influence $(p<0.05)$ on albumen relative weight (ALRW) and on yolk relative weight (YRW) of quails fed FPP. However, Ceylan et al. (2003) and Costa et al. (2010) did not find any significant changes in YRW in response to dietary $\mathrm{P}$ levels.

The regression equations are shown in Table 6.

Table 6 - Equations for the estimation of egg quality parameters of Japanese egg quails.

\begin{tabular}{|c|c|c|c|c|}
\hline Parameter & Equation & $R^{2}$ & Max point & Estimated Level (\%) \\
\hline ESW (CPP) & $E S W=0.92+036 C P P-0.68 C P P^{2}$ & 0.90 & $0.97 \mathrm{~g}$ & 0.26 \\
\hline ARW (FPP) & $A R W=59.47+0.62 F P P$ & 0.76 & ----- & $>0.50$ \\
\hline YRW (FPP) & $Y R W=32.44-0.76 F P P$ & 0.69 & ----- & $>0.50$ \\
\hline ESRW (CPP) & RESW $=7.88+3.44 C P P-6.08 C P P^{2}$ & 0.58 & $8.37 \%$ & 0.28 \\
\hline
\end{tabular}

$E S W=$ eggshell weight; $A R W=$ albumen relative weight; $Y R W=$ yolk relative weight; $E S R W=$ eggshell relative weight; $C P P=$ coarse particle size dicalcium phosphate; $F P P=$ fine particle size dicalcium phosphate

The analysis of tibiotarsus parameters (Table 9) shows no influence of dietary avP levels on bone $\mathrm{Ca}$ percentage of birds fed CPP, or on $\mathrm{P}$ and $\mathrm{Mg}$ percentage, independently of dicalcium phosphate particle size. Vieira et al. (2012) evaluated four avP levels ( 0.10 to $0.31 \%$ ) combined with three Ca levels $(2.0,2.5$, or $3 \%)$ in quail diets and did not find any influence on $\mathrm{Ca}$ bone content $(p>0.05)$. However, those authors reported a linear effect $(p>0.05)$ of avP levels in the diets containing 3.0\% calcium on 
tibial calcium content, whereas Costa et al. (2007), evaluating five avP levels (0.15 to $0.55 \%$ ) in a diet with $3.2 \% \mathrm{Ca}$, obtained a quadratic response of $\mathrm{P}$ bone percentage.

Bone ash content presented a quadratic response to increasing dietary avP levels (Table 7 ), with an estimated maximum point at $0,377 \%$ avP. This result is not consistent with the findings of Araujo et al. (2010), who fed commercial laying hens with diets three avP levels $(0.28,0.38$, or $0.48 \%)$ from two fine and coarse particle size phosphate and did not detect any significant changes in bone ash content.

Table 7 - Composition of tibiotarsus of Japanese quails.

\begin{tabular}{|c|c|c|c|c|c|c|c|c|}
\hline \multirow{2}{*}{$\operatorname{avP}\left(\mathrm{g} \mathrm{kg}^{-1}\right)$} & \multicolumn{2}{|c|}{ Ash (\%) } & \multicolumn{2}{|c|}{ Calcium (\%) } & \multicolumn{2}{|c|}{ Phosphorus(\%) } & \multicolumn{2}{|c|}{ Magnesium (\%) } \\
\hline & FPP & CPP & FPP & CPP & FPP & CPP & FPP & CPP \\
\hline 1.0 & 52.19 & 52.19 & 23.85 & 23.85 & 16.38 & 16.38 & 1.82 & 1.84 \\
\hline 2.0 & 52.51 & 53.71 & 22.22 & 21.38 & 16.65 & 16.11 & 2.96 & 1.98 \\
\hline 3.0 & 54.44 & 54.14 & 21.39 & 21.77 & 16.28 & 16.23 & 1.91 & 2.10 \\
\hline 4.0 & 56.09 & 54.38 & 20.33 & 21.82 & 16.23 & 16.64 & 2.10 & 1.88 \\
\hline 5.0 & 53.63 & 53.99 & 21.13 & 22.22 & 16.35 & 16.97 & 1.95 & 2.16 \\
\hline Significance & $P \leq 0.001$ & $P \leq 0.055$ & $P \leq 0.008$ & $p>0.12$ & $p>0.05$ & $p>0.05$ & $p>0.05$ & $p>0.05$ \\
\hline Effect & Q & NS & L & NS & NS & NS & NS & NS \\
\hline $\mathrm{CV}(\%)$ & \multicolumn{2}{|c|}{2.73} & \multicolumn{2}{|c|}{10.72} & \multicolumn{2}{|c|}{10.59} & \multicolumn{2}{|c|}{24.07} \\
\hline Parameter & \multicolumn{2}{|c|}{ Equation } & \multicolumn{2}{|c|}{$R^{2}$} & \multicolumn{2}{|c|}{ Max point } & \multicolumn{2}{|c|}{ Estimated Level (\%) } \\
\hline Ash (FPP) & \multicolumn{2}{|c|}{$\mathrm{MM}=48.91+31.54 \mathrm{FPP}-41.80 \mathrm{FPP}^{2}$} & \multicolumn{2}{|c|}{0.80} & \multicolumn{2}{|c|}{$54.85 \%$} & \multicolumn{2}{|c|}{0.377} \\
\hline Calcium (FPP) & \multicolumn{2}{|c|}{$\mathrm{Ca}=23.99-7.34 \mathrm{FPP}$} & \multicolumn{2}{|c|}{0.72} & \multicolumn{2}{|c|}{----- } & \multicolumn{2}{|c|}{$>0.5$} \\
\hline
\end{tabular}

$\mathrm{CPP}=$ coarse particle size dicalcium phosphate; $\mathrm{FPP}=$ fine particle size dicalcium phosphate.

The level of $1.0 \mathrm{~g} \mathrm{~kg}-1$ of available phosphorus refers to the basal diet with no addition of dicalcium phosphate.

On the other hand, Ca bone content linearly decreased as dietary avP levels increased (Table 9) when birds were fed FPP, but not CPP. This may be explained by the fact that, when diets with increasing inclusion levels of fine dicalcium phosphate are fed, $\mathrm{P}$ absorption sites are saturated due to the high availability of ionic P (Angel, 2010; Pereira, et al., 2009), compromising Ca to $P$ ratio and leading to the formation of insoluble phosphates, causing the animal to mobilize bone hydroxyapatite to meet its daily requirement (Pereira, et al., 2009). However, Garcia et al. (2000) evaluated similar avP levels (0.27 to $0.42 \%$ ) at four Ca levels (2.5 to $4 \%$ ) in quail diets, but did not detect any influence of avP levels on $\mathrm{Ca}$ bone percentage $(p>0.05)$, possibly because $C a: P$ ratio was maintained in the evaluated diets.

The results of the present study indicate that the recommended dietary available phosphorus levels for 20- to 32-wk-old laying Japanese quails depends on dicalcium phosphate particle size. When using fine particle size dicalcium phosphate $(148 \mu \mathrm{m})$, the recommended dietary avP level is $0.44 \%$, which corresponds to an intake of $113 \mathrm{mg}$ avP/bird/day, whereas for coarse particle size dicalcium phosphate $(0.325 \mu \mathrm{m})$, the avP recommendation is $0.385 \%$, corresponding an intake of $95.3 \mathrm{mg}$ avP/bird/day.

\section{REFERENCES}

Almeida Paz ICL, Mendes AA, Balog AA, Komiyama CM, Takahashi SE, Almeida ICL, et al. Calcium effect in bone and egg quality of the hens. Revista Archivos de Zootecnia 2009:58(222):173-183.
Amoah JK, Martin EA, Barroga AJ, Garillo EP, Domingo I. Calcium and phosphorus requirements of Japanese quail layers. Journal of Applied Biosciences 2012:54:3892-3900.

Angel R. Calcium and phosphorus requirements in poultry. Proceedings of the 1st International Phytase Summit; 2010; Washington. USA. p.6571.

Araújo LF, Junqueira OM, Araújo CSS, Savietto D, Albuquerque R, Barbosa LCGS. Níveis de fósforo disponível e tamanho de partícula do fosfato bicálcico na dieta de poedeiras comerciais de 24 a 58 semanas de idade. Revista Brasileira de Zootecnia 2010;39:1223-1227.

Ceylan N, Scheideler SE, Stilbom HL. High available phosphorus corn and phytase in layer diets. Poultry Science 2003;82:789-795.

Costa CHR, Barreto SLT, Gomes PC, Hosoda LH, Lipari CA, Lima HJA. Balance of calcium and phosphorus and study of these minerals in diets for Japanese quails (from 45 to 57 weeks of age). Revista Brasileira de Zootecnia 2010a:39(8):1748-1755.

Costa CHR, Barreto SLT, Moura WCO, Reis RS, Leite CDS, Maia GVC. Níveis de fósforo e cálcio em dietas para codornas japonesas em postura. Revista Brasileira de Zootecnia 2007;36:2037-2046.

Dimeglio L, Imel E. Calcium and phosphate: hormonal regulation and metabolism. In: Burr DB, Allen MR, editors. Basic and applied bone biology. $2^{\text {nd }}$ ed. New York: Academic Press; 2019. p.257-282.

Flemming E. Controlling late egg size. World Poultry 2005;21:14-15.

Furtado MAO. Determinação da biodisponibilidade de fósforo em suplementos de fósforo para aves e suínos [dissertation]. Belo Horizonte (MG): Universidade Federal de Minas Gerais; 1991.

Garcia J, Murakami AE, Martins EN, Furlan AC. exigências nutricionais de cálcio e fósforo para codornas japonesas (Coturnix coturnixjaponica) em postura. Acta Scientiarum 2000;22(3):733-739.

Gonzalez E. Ingestão de alimentos: mecanismos regulatórios. In: Macari M, Furlan RL, Gonzalez E, editors. Fisiologia aviária aplicada a frangos de corte. Jaboticabal: FUNEP. 2002; p.187-199. 
Griffith G, Schexnailder R. The relation of dietary particle size to phosphorus availability in purified diets. Poultry Science 1970;49:1271-1274.

Henderson SM, Perry RL. Agricultural process enginering. New York: John Wiley and Sons; 1995.

Li X, Zhang D, Yang TY, Bryden WL. Phosphorus bioavailability: a key aspect for conserving this critical animal feed resource with reference to broiler nutrition. Agriculture 2016;6:25.

Oderkirk A. The Role of calcium phosphorus and vitamin D3 in egg eggshell and bone formation. Poultry Fact Sheet 1998;3.

Pereira GAP, Genaro PS, Pinheiro MM, Szejnfel DVL, Martini LA. Dietary calcium: strategies to optimize intake. Revista Brasileira de Reumatologia 2009;49(2).

Ribeiro CLN, Barreto SLT, Reisi RS, Muniz JCL, Viana GS, Ribeiro Junior $V$, et al. The Effect of calcium and available phosphorus levels on performance, egg quality and bone characteristics of japanese quails at end of the egg-production phase. Revista Brasileira de Ciência Avícola 2016;18:33-40.
Rostagno HS. Tabelas brasileiras para aves e suínos: composição de alimentos e exigências nutricionais. $3^{\text {a }}$ ed. Viçosa: Universidade Federal de Viçosa; 2011.

Runho RC, Gomes PC, Rostagno HS, et al. Exigência de fósforo disponível para frangos de corte machos e fêmeas de 1 a 21 dias de idade. Revista Brasileira de Zootecnia 2001;30(1):187-196.

SAEG. Sistema para análises estatísticas, versão 9.1. Viçosa: Universidade Federal de Viçosa; 1997.

Salter Wt, Fulton C, Angier F. Studies in calcium and phosphorus metabolism. The Journal of Nutrition 1931;1(4):1-13.

Silva DJ. Análise de alimentos: métodos químicos e biológicos. $3^{\mathrm{a}}$ ed. Viçosa: Universidade Federal de Viçosa; 2002.

Vieira DVG, Barreto SLT, Jesus LFD, Valeriano MH, Silva LFF, Mencalha R, et al. Exigências de cálcio e de fósforo disponível para codornas japonesas de 26 a 38 semanas de idade. Revista Brasileira de Saúde e Produção Animal 2012;13:204-213. 
